\title{
MEDICINE
}

\section{INDICATORS OF ENDOTHELIAL DYSFUNCTION IN PREGNANT WOMEN WITH GESTATIONAL DIABETES MELLITUS}

\author{
Avramenko T. $V$., \\ PhD, Assistant Professor Litvinov S. K., \\ PhD, Assistant Malinina O. B. \\ State Enterprise "Institute of Pediatrics, Obstetrics and Gynecology" named after Academician O.M. \\ Lukyanova \\ Vinnytsja National Pyrogov Memorial Medical University
}

DOI: https://doi.org/10.31435/rsglobal_wos/30042019/6443

\section{ARTICLE INFO}

Received: 12 February 2019

Accepted: 22 April 2019

Published: 30 April 2019

\section{KEYWORDS}

diabetes mellitus,

prostaglandins,

endothelial dysfunction,

hyperglycemia,

microangiopathy

\section{ABSTRACT}

The article presents the results of the discovery of violation of concentration of prostaglandins and endothelial factors in the blood of pregnant women with gestational diabetes, depending on the nature of the compensation of the disease.

Citation: Avramenko T. V., Litvinov S. K., Malinina O. B. (2019) Indicators of Endothelial Dysfunction in Pregnant Women with Gestational Diabetes Mellitus. International Academy Journal Web of Scholar. 4(34). doi: 10.31435/rsglobal_wos/30042019/6443

Copyright: (C) 2019 Avramenko T. V., Litvinov S. K., Malinina O. B. This is an open-access article distributed under the terms of the Creative Commons Attribution License (CC BY). The use, distribution or reproduction in other forums is permitted, provided the original author(s) or licensor are credited and that the original publication in this journal is cited, in accordance with accepted academic practice. No use, distribution or reproduction is permitted which does not comply with these terms.

Introduction. In the 1960s, the British pathologist of Australian origin Howard Flory, first using an electron microscopy, established how macromolecules diffuse through the walls of the arteries and veins of various organs. He first discovered the membrane microstructure of endothelium and intercellular compounds involved in the transport processes. The works of G. Flory served as the basis for today's ideas about endothelium. Endothelial cells form a single layer of cells lining the vascular and lymphatic system, which forms the barrier between blood and lymph in vessels and surrounding tissues. The total area of the endothelium is over $1000 \mathrm{~m} 2[1,7,8]$.

Vascular changes that arise in gestational diabetes mellitus are the main cause of complications during pregnancy and are directly related to the complications of the fetus. There is no doubt that such changes have a polyethiological character and further development of science can bring much new in their understanding [2].

Diabetic microangiopathy is universal and manifests itself both in the blood vessels of the kidneys, retina, and in the vessels of the fetoplacental complex. Defeat of endothelial wall is directly related to chronic hyperglycemia, which is realized not as an independent mechanism, but through other processes - sorbitol shunt or non-enzyme glycation of proteins, and others. The most harmful effects are irreversible end-products of glycation, which alter the structure and metabolism of the main proteins of body. When reacting with endothelial cells, they cause damage to them. This leads to an 
increase in the permeability of the endothelial barrier for low molecular weight substances, as well as the ejection of procoagulant factors that provoke thrombotic occlusion of the capillaries and the development of coagulopathies $[2,6]$.

The products of irreversible glycation are formed in the body of a patient with diabetes quite quickly, within a few months, after which even the most thorough compensation of metabolic disorders is no longer able to eliminate the presence of these products. The irreversibility of endproduct of non-enzyme glycation explains the progression of micro- and macrovascular complications, even with very good compensation for diabetes [2].

Traditionally, endothelial dysfunction is directly associated with imbalance in mediators that provide vascular tone regulation: endogenous vascular relaxation factors $(\mathrm{NO}$, natriuretic type $\mathrm{C}$ peptide) and constriction (endothelin-1, prostaglandin F $2 \alpha$ ). The study of these indicators can provide information on the severity of endothelial dysfunction $[1,4,7]$.

A large, though very fragmented material has been accumulated on the role of endothelial dysfunction in the pathogenesis of vascular complications in diabetes mellitus during pregnancy. At the same time, data on the manifestation of this pathology in women with gestational diabetes mellitus is absent.

Materials and methods.

To solve the problems, 150 pregnant women with diabetes mellitus were examined and examined at the maternity ward for pregnant women with metabolic disorders and fetal malformations of the IPAG NAMS Ukraine.

The control group consisted of patients in whom the gestational diabetes (GD) was not detected; their pregnancy went through without complications; severe extragenital pathology was not observed.

Taking into account the features of therapy for correction of carbohydrate metabolism, 105 (70.0\%) patients were diagnosed with GI class A1, that is, the pathology in which normalization of carbohydrate metabolism was achieved only by diet. In 45 (30.0\%) women diagnosed with grade A2 DD; they used insulin therapy and / or metformin to normalize the carbohydrate metabolism along with the diet.

The state of the endothelial function was assessed by the prostaglandin E2 (PGE2), prostaglandin F2 $\alpha$ (PGF2 $\alpha$ ), prostacyclin (PGI2), thromboxane B2 (TxB2), endothelin-1 (ET-1), nitric oxide (NO), L- arginine on the immune enzyme analyzer «Sunrise» of the firm «Tecan».

Results.

The main endothelial vasoconstrictors, above all, are endothelin-1. In the study, it was found that endothelin-1 indices in women with GCS practically doubled these rates in healthy pregnant women $(16.4 \pm 1.4$ and $8.3 \pm 1.4(\mathrm{p}<0.001)$. Comparison of this indicator in groups A1 and A2 showed that women with GCD, whose compensation was achieved by diet, had no significant deviations from the indicator of healthy pregnant women $(8.9 \pm 1.7(p>0.05)$. At the same time, the amount of endothelin-1 significantly increased in women with GCD, whose compensation was achieved by insulin $(21.8 \pm 1.6(\mathrm{p}<0.01)$. See Table 1 .

Determination of the prostaglandin indexes of different groups in women with GCD showed a significant imbalance with a marked prevalence of the effect of prostaglandins on the vasoconstrictor effect $(\mathrm{FH} 2 \mathrm{FV}-1.5$ times, thromboxane $(\mathrm{T} \times \mathrm{B} 2)-1.6$ fold) and decreased prostaglandins depressor activity (PGE2 in 2.6 times, PGI2 - 1.3 times) compared with healthy pregnant women. Analysis of the level of prostaglandins in groups A1 and A2 determined that there was no significant difference in the level of prostaglandins in depressor activity. PGE2 was $2.79 \pm 0.29 \mathrm{ng} / \mathrm{ml}$ and $2.38 \pm 0.29 \mathrm{ng} / \mathrm{ml}$ in groups A1 and A2 (p>0.05) and PGI2 was 43.6 $\pm 3.5 \mathrm{pg} / \mathrm{ml}$ and 41, $6 \pm 3.1 \mathrm{pg} / \mathrm{ml}$, respectively (p>0.05). See Table 1. However, in women, the compensation of HIC that was achieved by insulin had a significant increase in prostaglandins vasoconstrictor effect compared with pregnant women at GCD, whose compensation was achieved by diet (GH F2 $\alpha-0,97 \pm 0,06 \mathrm{ng} / \mathrm{ml}$ and $0,66 \pm 0.05 \mathrm{ng} /$ $\mathrm{ml}$ respectively $(\mathrm{p}<0.001)$.

Despite the fact that identification of nitric oxide (NO) as a biological agent produced by the endothelium to regulate the vascular wall tone occurred 38 years ago, it remains the main factor in vascular relaxation. The determination of $\mathrm{NO}$ revealed its significant decrease in women of the A2 group compared with the NO index in healthy pregnant women $(2.09 \pm 0.12 \gamma / \mathrm{mol}$ and $3.7 \pm 0.4 \gamma /$ mol respectively $(\mathrm{p}<0.001)$. NO indices healthy women and women of the A1 group were similar (3.7 $\pm 0.4 \gamma /$ moll and $3.14 \pm 0.13$ respectively) $(\mathrm{p}>0.05)$ Similar results were obtained for L-arginine. 
Table 1. Concentration of prostaglandins and endothelial factors in the blood of pregnant women with gestational diabetes, depending on the nature of the compensation of the disease

\begin{tabular}{|c|c|c|c|c|c|c|}
\hline \multirow{3}{*}{ Indicator } & \multirow{3}{*}{$\begin{array}{r}\text { Healthy } \\
1 \mathrm{st}\end{array}$} & \multicolumn{2}{|c|}{ Patients with GD } & \multirow{3}{*}{$P_{1-2}$} & \multirow{3}{*}{$P_{1-3}$} & \multirow{3}{*}{$\mathrm{P}_{2-3}$} \\
\hline & & \multirow{2}{*}{$\begin{array}{c}\text { class A1 } \\
\text { 2nd }\end{array}$} & \multirow{2}{*}{$\frac{\text { class A2 }}{3 \mathrm{~d}}$} & & & \\
\hline & & & & & & \\
\hline $\mathrm{PGE}_{2}, \mathrm{ng} / \mathrm{ml}$ & $6,45 \pm 0,21$ & $2,79 \pm 0,29$ & $2,38 \pm 0,29$ & $<0,001$ & $<0,001$ & $>0,05$ \\
\hline $\mathrm{PGF}_{2 \alpha}, \mathrm{ng} / \mathrm{ml}$ & $0,39 \pm 0,05$ & $0,66 \pm 0,05$ & $0,97 \pm 0,06$ & $<0,001$ & $<0,001$ & $<0,001$ \\
\hline PGF $2 \alpha /$ ПГЕ2 & 0,06 & 0,24 & 0,41 & - & - & - \\
\hline $\mathrm{PGI}_{2}, \mathrm{pg} / \mathrm{ml}$ & $86,4 \pm 8,5$ & $43,6 \pm 3,5$ & $41,6 \pm 3,1$ & $>0,05$ & $<0,001$ & $>0,05$ \\
\hline $\mathrm{TxB}_{2}, \mathrm{pg} / \mathrm{ml}$ & $40,5 \pm 4,5$ & $74,7 \pm 3,9$ & $79,9 \pm 4,0$ & $<0,001$ & $<0,001$ & $>0,05$ \\
\hline TxB2,/PGI2 & 0,47 & 1,71 & 1,92 & - & - & - \\
\hline Ет- $1, \mathrm{pg} / \mathrm{ml}$ & $8,3 \pm 1,3$ & $8,9 \pm 1,7$ & $21,8 \pm 1,6$ & $>0,05$ & $<0,001$ & $<0,001$ \\
\hline NO, $\gamma /$ moll & $3,7 \pm 0,4$ & $3,14 \pm 0,13$ & $2,09 \pm 0,12$ & $>0,05$ & $<0,001$ & $<0,001$ \\
\hline $\begin{array}{c}\text { L-arginin, } \\
\text { mmoll/1 }\end{array}$ & $50,7 \pm 0,4$ & $49,7 \pm 1,5$ & $32,4 \pm 1,5$ & $>0,05$ & $<0,001$ & $<0,01$ \\
\hline ET-1-/NO & 2,23 & 3,2 & 10,4 & - & - & - \\
\hline
\end{tabular}

Conclusions. Thus, an analysis of endothelial function in comparator groups of women allowed us to conclude that the endothelium is a target for gestational diabetes mellitus. The imbalance between the substances of pressor and depressor activity with the predominance of the first has a reliable association with the type of gestational diabetes mellitus. However, the data obtained are mediated. Only further study of the typical complications in comparative groups of women with GD can give a true picture of the impact of this pathology on the course of pregnancy.

\section{REFERENCES}

1. Васина, Л. В. \& Петрищев, Н.Н. (2017). Эндотелиальная дисфункция и ее основные маркеры. Регионарное кровообращение и микроииркуляиия, 16 (1), 4-12.

2. Дедов, И.И. \& Шестаков, М.В. (2003). Сахарный диабет. Руководство для врачей. Универсум Паблишинг, 455.

3. Дикур, О.Н. \& Копылов, Ф.Ю (2014). Клиническое значение эндотелиальной дисфункции при беременности как компонента комплексной оценки риска развития преэклампсии. Архив акушерства и гинекологии им. В. Ф. Снегирева, 2, 7-13.

4. Жаринова, В.Ю. (2015). Эндотелиальная дисфункция как мультидисциплинарная проблема. Кровообіг та гемостаз, 1-2, 9-15.

5. Климов, В.А. (2014). Эндотелиальная дисфункция при осложненном течении беременности. Збірник наукових пращь асоиіації акушерів-гінекологів України, 1/2 (33/34), 165-167.

6. Комилова, М.С. \& Пахомова, Ж.Е. (2015). Значение эндотелия в развитии осложнений гестационного периода. Российский вестник акушера-гинеколога, 1, 18-23.

7. Попова, А.А., Березикова, Е.Н. \& Маянская, С.Д. (2010). Эндотелиальная дисфункция и механизмы её формирования. Сибирское медичинское обозрение, 64 (4), 7-11.

8. Durand, M.J. (2013). Diversity in Mechanisms of Endothelium Dependent Vasodilation in Health and Disease. Microcirculation, 20(3), 239-247. 